\title{
PHYSIOLOGICAL FACTORS AFFECTING AIRWAY RESISTANCE IN NORMAL SUBJECTS AND IN PATIENTS WITH OBSTRUCTIVE RESPIRATORY DISEASE *
}

\author{
By JOHN BUTLER, $\dagger$ COLIN G. CARO, RAPHAEL ALCALA $\ddagger$ AND \\ ARTHUR B. DUBOIS § \\ (From the Department of Physiology of the Graduate School of Medicine, University of \\ Pennsylvania, Philadelphia, Pa.)
}

(Submitted for publication October 14, 1959; accepted December 4, 1959)

Although the airway conductance ${ }^{1}$ increases at larger lung volumes in normal subjects (1), it is reduced in patients with asthma or emphysema who are breathing with a large functional residual capacity (FRC) (2). We have therefore tried to assess the influence of other factors which might affect the airway conductance in both normal subjects and in patients with asthma, bronchitis and emphysema. These include the interrelationship of lung volume, lung elastic pressure and airway conductance, the effect of exercise, forced breathing and normal aging, and the composition of the respired gas and bronchomotor drugs. We investigated the balance of forces regulating the diameter of the airway lumen, i.e., the tone of the airway wall, directed inward, opposed by the traction of the lung tissues, directed outward. We studied whether, in normal subjects, this balance was altered by bronchmotor drugs or by a change in lung elastic pressure following chest strapping, and whether in patients with asthma, the airway conductance/lung volume relationship was altered after forced breathing or exercise. Patterns of disturbance leading to air trapping

\footnotetext{
* Supported in part by a contract between the University of Pennsylvania and the Army Chemical Center Medical Laboratories.

$\dagger$ Rockefeller Traveling Fellow in Medicine. Present address: Department of Medicine, University of Manchester, Manchester, England.

$\ddagger$ Fellow of the Doherty Charitable Foundation, New York, N. Y. Present address: Clinica de la Concepcion, Madrid, Spain.

$\S$ Established Investigator of the American Heart Association.

1 Airway conductance, the reciprocal of airway resistance, is defined as the rate of airflow at the mouth for unit pressure difference between alveolus and mouth. It was measured over the range of 0 to $0.5 \mathrm{~L}$ per second of inspiratory airflow.
}

were studied in patients who had emphysema or bronchitis of toxic etiology.

\section{METHODS}

Airway resistance and thoracic gas volume were measured during panting ${ }^{2}$ using an upright body plethysmograph (2). The methods hinge on Boyle's law for compression of gases. Volume change owing to compression of gas inside the thorax is measured by the equal and opposite small displacement of gas around the body. After appropriate calibrations, the intrathoracic gas volume changes found when rebreathing the air of the chamber through a heated flowmeter are converted mathematically to alveolar pressure changes, thence to airway resistance and airway conductance; or, when breathing against a closed shutter and manometer, to thoracic gas volume. In practice, these values are read directly from a precalibrated scale and protractor on the face of an oscilloscope, thus reducing labor. Esophageal pressure and mouth pressures were measured alternately using a capacitance manometer and Brush recorder. Lung elastic pressure (3) at each lung volume was measured as mean esophageal pressure, ${ }^{3}$ while panting (4). Chest constriction was accomplished by binding the subject's chest or abdomen, in the expiratory position, with adhesive tape or a long strip of rubber (4). Other tests of pulmonary function were performed according to generally accepted methods. All measurements were made with the subject in the sitting position. Lung volumes are expressed at BTPS.

\section{RESULTS ON HEALTHY SUBJECTS}

Spontaneous variation of airway resistance with time. The airway resistance of six healthy subjects was studied at 20 minute intervals over a 2 hour period. Measurements were made during

2 The larynx was maintained wide open while panting at different lung volumes as was seen in two normal subjects who were investigated by indirect laryngoscopy.

${ }^{3}$ Lung elastic pressure is equivalent to static intrapleural pressure and represents the pressure derived from the elastic properties of the lung. 


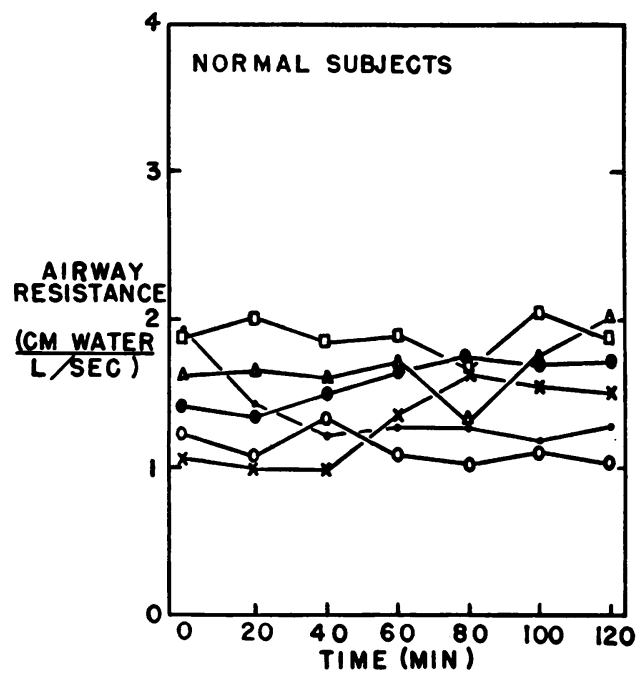

Fig. 1. Variation of AIRWAy RESistance With time.

panting at about the FRC. The mean value at each sitting was calculated from five consecutive readings. The airway resistance changed but little during the two hours (Figure 1).

Values for airway resistance in old age. Airway resistance measured in ten healthy colored subjects, ranging in age from 75 to 90 years, was

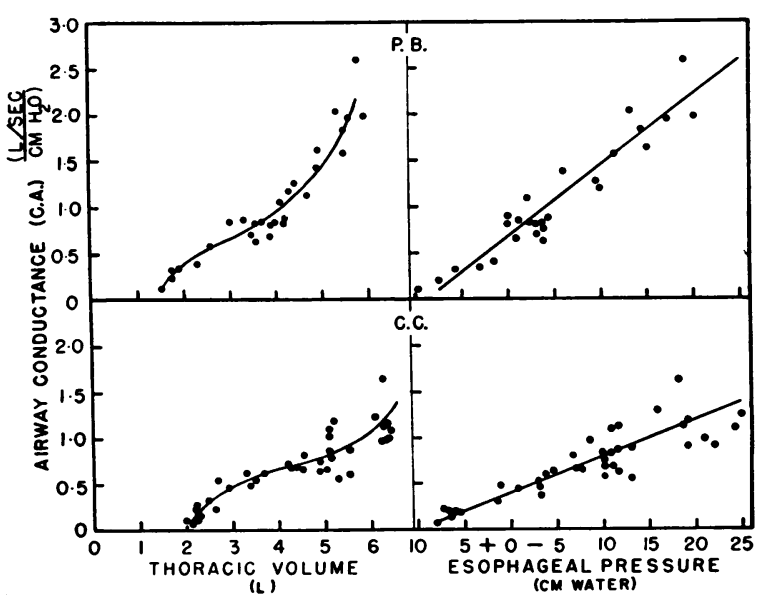

Fig. 2. ReLationship of AIRWAy CONDUCtance to THORACIC GAS VOLUME AND ESOPHAGEAL PRESSURE.

similar to that of younger people. These subjects had a reduction of maximal breathing capacity, similar to that found by others, and of maximal flow rates. Reduction in the maximum pressure generated by the respiratory muscles and increased lung tissue resistance probably contributed to the diminution of maximal flow rates. Values are listed in Table I.

TABLE I

Mechanics of breathing in ten normal subjects 75 to 90 years of age*

\begin{tabular}{|c|c|c|c|c|}
\hline & \multirow{2}{*}{$\begin{array}{l}\text { Average, } \\
\text { young } \\
\text { adults }\end{array}$} & \multicolumn{2}{|c|}{ Values in older subjects } & \multirow[b]{2}{*}{ Units } \\
\hline & & Mean & Range & \\
\hline $\begin{array}{l}\text { Total pulmonary resistance, } \\
\text { panting }\end{array}$ & & 2.0 & $1.1-3.2$ & $\mathrm{~cm} \mathrm{H}_{2} \mathrm{O} / \mathrm{L} / \mathrm{sec}$ \\
\hline Airway resistance, panting & $0.6-2.4$ & 1.3 & $0.7-2.1$ & $\mathrm{~cm} \mathrm{H} \mathrm{H}_{2} \mathrm{O} / \mathrm{L} / \mathrm{sec}$ \\
\hline Pulmonary tissue resistance & $0.0-0.4$ & 0.7 & $0.03-1.9$ & $\mathrm{~cm} \mathrm{H}_{2} \mathrm{O} / \mathrm{L} / \mathrm{sec}$ \\
\hline $\begin{array}{l}\text { Pulmonary compliance, quiet } \\
\text { breathing }\end{array}$ & 0.17 & 0.12 & $0.08-0.20$ & $\mathrm{~L} / \mathrm{cm} \mathrm{H}{ }_{2} \mathrm{O}$ \\
\hline $\begin{array}{l}\text { Airway conductance per unit } \\
\text { lung volume (measured at } \\
\text { resting lung volume) }\end{array}$ & $0.13-0.34$ & 0.29 & $0.12-0.37$ & $\mathrm{~L} / \mathrm{sec} / \mathrm{cm} \mathrm{H}_{2} \mathrm{O} / \mathrm{L}$ \\
\hline $\begin{array}{l}\text { Pulmonary compliance per } \\
\text { unit FRC }\end{array}$ & $0.038-0.070$ & 0.045 & $0.021-0.072$ & $\mathrm{~L} / \mathrm{cm} \mathrm{H}_{2} \mathrm{O} / \mathrm{L}$ \\
\hline Maximal expiratory flow rate & $400-500$ & 132 & $50-250$ & $\mathrm{~L} / \mathrm{min}$ \\
\hline Maximal inspiratory flow rate & $300-500$ & 135 & $60-300$ & $\mathrm{~L} / \mathrm{min}$ \\
\hline $\begin{array}{c}\text { Maximal voluntary mouth pressure } \\
\text { Expiratory: Males } \\
\text { Females } \\
\text { Inspiratory: Males } \\
\text { Females }\end{array}$ & $\begin{array}{l}54-115 \\
57 \\
60-90 \\
44\end{array}$ & $\begin{array}{l}58 \\
32 \\
33 \\
18\end{array}$ & $\begin{array}{r}38-80 \\
22-47 \\
26-36 \\
8-25\end{array}$ & 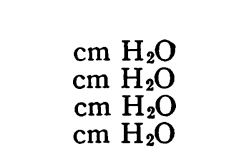 \\
\hline
\end{tabular}

* Resistances were measured over the range 0 to $0.5 \mathrm{~L} / \mathrm{sec}$ of inspiratory airflow. Maximal flow rates were measured between 0.2 and $1.2 \mathrm{~L}$ of inspired or expired volume. Ranges have been given, in preference to standard deviation, because of skew distribution about the mean. Maximal voluntary mouth pressures were measured at a volume close to FRC. A small leak was present in the occluded airway to eliminate effects due to the oropharyngeal muscles acting with a closed glottis. 


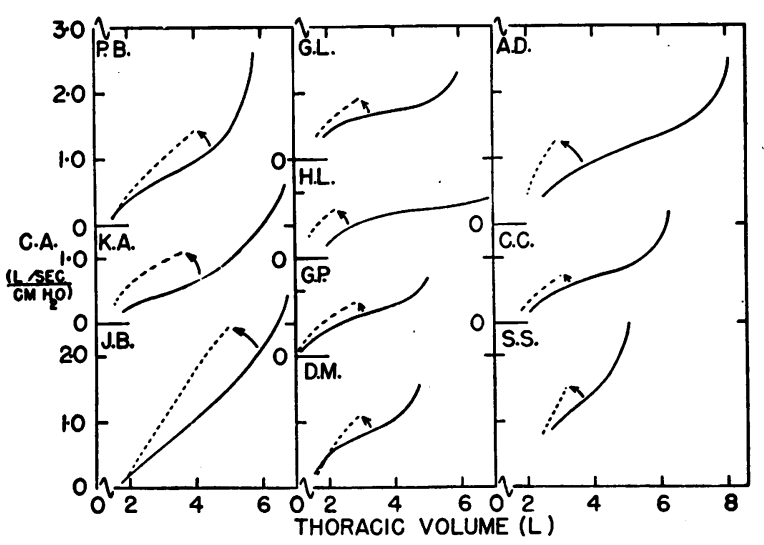

Fig. 3. EFFECT OF CHeSt STRAPPING ON RELATIONSHIP of conduCtance to volume. Solid line before, broken line after, chest strapping. A shift in the conductance volume line was observed in each of 10 subjects.

Lung elastic pressure and airway conductance; the effect of chest strapping. Airway conductance generally showed a curvilinear relationship to thoracic gas volume (Figure 2, left). Replotting the same airway conductance values versus mean esophageal pressure appeared to yield a straighter line (Figure 2, right).

A change of the pressure-volume curve of the lungs resulted from tightly strapping the chest or abdomen (4); esophageal pressure was more negative at any lung volume above the residual volume (RV). Thus, at the same lung volumes, the lung elastic pressure was greater after chest restriction than in the control state. At each lung volume, airway conductance was also greater after chest strapping than it had been before (Figure

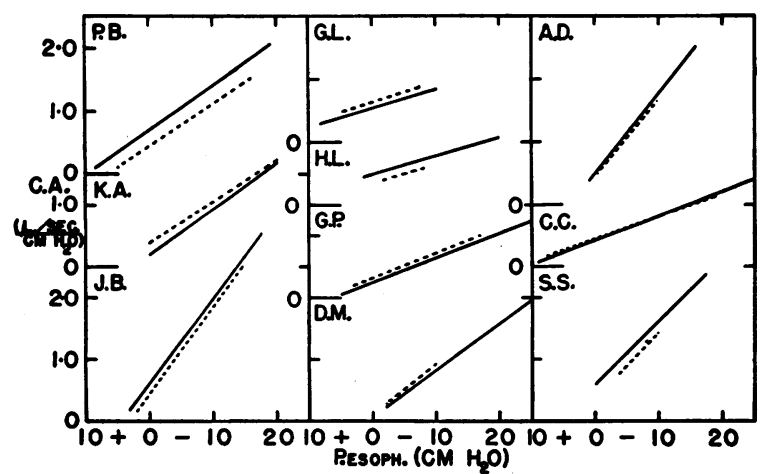

Fig. 4. EFfeCt OF CHest STRAPPING ON RELATIONSHIP OF CONDUCTANCE TO ESOPHAGEAL PRESSURE. Solid line before, broken line after, chest strapping. No average change in the conductance-pressure plot was observed.
3). When airway conductance was related to lung elastic pressure (Figure 4), measured as mean esophageal pressure at each lung volume, the curves obtained after chest strapping were not on the average different from those obtained in the control state. During recovery after removal of the strapping (Figure 5) the lung elastic pressure-volume relationship formed a large hysteresis loop. The airway conductance-lung volume relationship passed through a similar loop on the return to normal. These results indicated that lung elastic pressure was the common factor responsible for the relationship between airway conductance and lung volume previously reported (1).

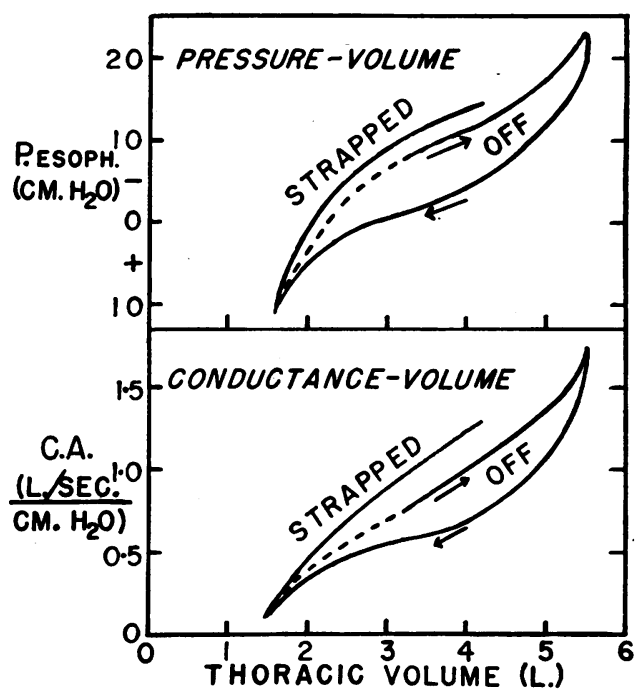

Fig. 5. RELATIONSHIPS DURING FIRST INSPIRATION AFTER REMOVAL OF STRAPPING. Pressure volume (top) and conductance volume (bottom) plots followed hysteresis loops similar in appearance.

Effect of exercise or forced breathing. Data obtained before and after exercise or forced breathing are presented in Table II. After exercise the subjects breathed in a slightly more inspiratory position, thereby slightly reducing the airway resistance (1). Forced breaths, consisting of vital capacity and maximal flow rate determinations, failed to change the airway resistance of normal subjects.

Effect of oxygen or carbon dioxide. Oxygen administered by a closely fitting, airtight face mask failed to produce any change in airway resistance whether it was measured immediately after the onset of oxygen breathing or at inter- 
TABLE II

Factors which do not appear to affect airway resistance: $\mathrm{O}_{2}, \mathrm{CO}_{2}$, water aerosol, exercise, and forced breathing

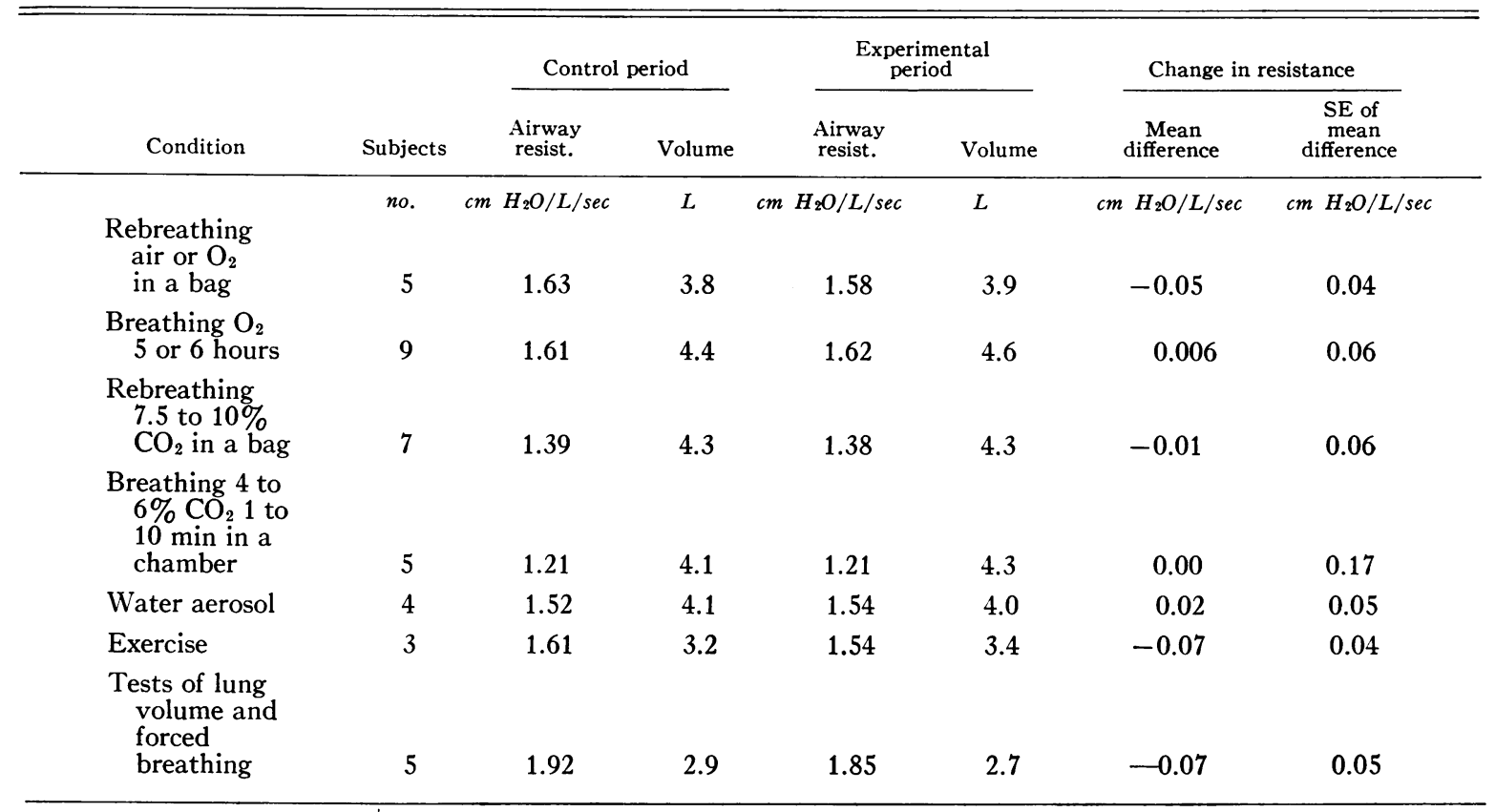

vals during an exposure of 5 to 6 hours' duration (Table II). Four to 10 per cent carbon dioxide administered in the respired air over periods of time lasting up to 10 minutes gave variable results, but there was no change in the average airway resistance of the group (Table II).

\section{RESULTS ON PATIENTS}

The relationship between airway conductance and lung volume in asthma and emphysema. The airway conductance was measured at different lung volumes in healthy subjects, in symptomatic and asymptomatic asthmatic patients, and in patients with emphysema. Airway conductance was plotted against lung volume and the curve of best fit was drawn by inspection. From the curve, the volume at which airway conductance appeared to approach zero (1) and the airway conductance at the FRC were read. The average slope of the curve of airway conductance versus volume was

TABLE III

Characteristic alterations in the interrelation of airway conductance and lung volume in patients with asthma and emphysema, and values (in parentheses) following isoproterenol aerosol, 1:200 solution *

\begin{tabular}{|c|c|c|c|c|c|c|c|c|}
\hline \multicolumn{2}{|l|}{ Subjects } & $\begin{array}{l}\text { Airway conduc- } \\
\text { tance at FRC }\end{array}$ & \multicolumn{2}{|c|}{ FRC } & \multicolumn{2}{|c|}{$\begin{array}{l}\text { Conduct. change } \\
\div \text { volume change }\end{array}$} & \multicolumn{2}{|c|}{$\begin{array}{l}\text { Lung gas volume } \\
\text { at zero con- } \\
\text { ductance }\end{array}$} \\
\hline & no. & $\mathrm{L} / \mathrm{sec} / \mathrm{cm} \mathrm{H}_{2} \mathrm{O}$ & & $L$ & $L / \mathrm{sec} /$ & $n \mathrm{H}_{2} \mathrm{O} / \mathrm{L}$ & & $L$ \\
\hline Normal & 5 & $0.60 \quad(0.77)$ & 2.6 & $(2.6)$ & 0.28 & $(0.50)$ & 0.8 & $(1.0)$ \\
\hline $\begin{array}{l}\text { Symptomless } \\
\text { asthma }\end{array}$ & 4 & 0.38 & 2.8 & & 0.28 & & 1.5 & \\
\hline Asthma & 3 & $(0.49)$ & 4.8 & $(4.1)$ & 0.09 & $(0.23)$ & 2.7 & (1.9) \\
\hline Emphysema & 5 & $(0.36)$ & 5.0 & (4.6) & 0.16 & $(0.29)$ & 3.8 & (3.4) \\
\hline
\end{tabular}

* In addition to these observations, atropine, 0.9 to $1.2 \mathrm{mg}$, subcutaneously, increased the ratio conductance/volume from 0.27 to 0.48 in four normal subjects; epinephrine, $0.4 \mathrm{ml}$ of a $1: 1,000$ solution, subcutaneously, changed the conductance from 0.67 (at $3.8 \mathrm{~L}$ ) to 0.76 (at $3.7 \mathrm{~L}$ ) in five normal subjects. The FRC's were measured by the plethysmographic method (5). 


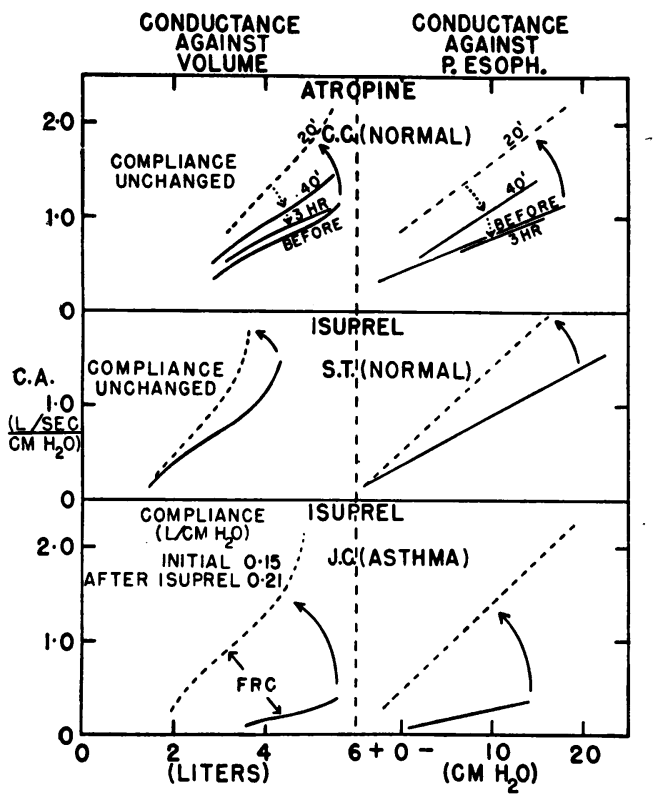

Fig. 6. THE EFFECT OF BRONCHODILATOR DRUGS ON THE RELATIONSHIP BETWEEN AIRWAY CONDUCTANCE AND LUNG VOLUME OR ESOPHAGEAL PRESSURE IN NORMAL SUBJECTS AND IN AN ASTHMATIC PATIENT. Left-hand diagrams relate conductance to volume. Right-hand diagrams relate conductance to esophageal pressure. Solid lines before, and broken lines after, bronchodilator. Time sequence of recovery from atropine shown in upper diagrams.

measured at the FRC. These values are shown in Figure 6 and Table III.

In both the symptomatic asthmatic patients and in the patients with emphysema, the FRC (5) was increased and the airway conductance, measured at the FRC, was reduced. The change in airway conductance per unit change in lung volume was less than normal, and there was an increase of the lung volume at which the extrapolated line of airway conductance approached zero. The failure of the increased FRC of these patients to restore normal airway conductance appeared to be due to the shift in position and lower slope of the airway conductance-lung volume relationship (Figure 6).

Effect of forced breathing or exercise. The asthmatic patients who were in symptomatic remission and not on therapeutic drugs had little spontaneous variation of airway resistance. However, after forced breathing, consisting of vital capacity and maximal flow rate determinations, airway resistance increased in the majority. The entire curve of airway conductance against lung volume (Table IV) had shifted. Brief, heavy exercise produced a similar response in two asthmatic subjects.

Effect of bronchodilator drugs. Administration of bronchodilator drugs altered the curve of airway conductance versus lung volume in normal subjects, in patients with asthma, and, to some extent, in patients with emphysema (Table III). That this was not attributable to an increase in lung elastic pressure was evident when airway

TABLE IV

Effect of fast vital capacity tests and exercise on airway conductance in asthmatic patients

\begin{tabular}{|c|c|c|c|c|c|c|c|c|}
\hline \multirow{2}{*}{$\begin{array}{l}\text { Procedure and } \\
\text { subjects }\end{array}$} & \multicolumn{2}{|c|}{$\begin{array}{c}\text { Airway conductance } \\
\text { at FRC }\end{array}$} & \multicolumn{2}{|c|}{ FRC } & \multicolumn{2}{|c|}{$\begin{array}{l}\text { Conduct. change } \\
\div \text { volume change }\end{array}$} & \multicolumn{2}{|c|}{$\begin{array}{l}\text { Lung gas volume } \\
\text { at zero con- } \\
\text { ductance }\end{array}$} \\
\hline & Before & After & Before & After & Before & After & Before & After \\
\hline & \multicolumn{2}{|c|}{$L / \mathrm{sec} / \mathrm{cm} \mathrm{H}_{2} \mathrm{O}$} & \multicolumn{2}{|c|}{$L$} & \multicolumn{2}{|c|}{$L / \mathrm{sec} / \mathrm{cm} \mathrm{H}_{2} \mathrm{O} / L$} & \multicolumn{2}{|c|}{$L$} \\
\hline 5 Normals* & 0.52 & 0.54 & 2.9 & 2.7 & 0.23 & 0.22 & 0.9 & 0.9 \\
\hline \multicolumn{9}{|l|}{$\begin{array}{l}\text { VC tests in } \\
\text { asthmatics }\end{array}$} \\
\hline $\begin{array}{l}\mathrm{ME} \dagger \\
\text { JC† } \\
\mathrm{LF} \dagger \\
\mathrm{MK} \\
\mathrm{MC}\end{array}$ & $\begin{array}{l}0.45 \\
0.45 \\
0.54 \\
0.74 \\
0.20\end{array}$ & $\begin{array}{l}0.21 \\
0.31 \\
0.32 \\
0.65 \\
0.20\end{array}$ & $\begin{array}{l}3.3 \\
3.7 \\
3.0 \\
2.4 \\
3.9\end{array}$ & $\begin{array}{l}3.5 \\
4.1 \\
3.0 \\
2.4 \\
4.0\end{array}$ & $\begin{array}{l}0.20 \\
0.19 \\
0.24 \\
0.29 \\
0.25\end{array}$ & $\begin{array}{l}0.13 \\
0.13 \\
0.18 \\
0.30 \\
0.11\end{array}$ & $\begin{array}{l}2.3 \\
2.0 \\
1.2 \\
1.0 \\
2.5\end{array}$ & $\begin{array}{l}2.9 \\
2.3 \\
1.6 \\
1.0 \\
3.0\end{array}$ \\
\hline \multicolumn{9}{|l|}{$\begin{array}{l}\text { Exercise in } \\
\text { asthmatics }\end{array}$} \\
\hline $\begin{array}{l}\mathrm{JC} \dagger \\
\text { DOt }\end{array}$ & $\begin{array}{l}0.39 \\
0.34\end{array}$ & $\begin{array}{l}0.25 \\
0.28\end{array}$ & $\begin{array}{l}2.6 \\
3.5\end{array}$ & $\begin{array}{l}2.8 \\
4.9\end{array}$ & 0.39 & 0.28 & 1.6 & 2.0 \\
\hline
\end{tabular}

* None of the normal subjects showed any significant change of values after vital capacity tests or exercise.

$\dagger$ These patients showed a significant change. The asthmatic patients, except MC, were asymptomatic at the onset. 
TABLE V

Tests of forced voluntary ventilation and airway resistance in youth, industrial bronchitis, and old age *

\begin{tabular}{|c|c|c|c|}
\hline & Youth & $\begin{array}{c}\text { Industrial } \\
\text { bronchitis† }\end{array}$ & Old age \\
\hline $\begin{array}{l}\text { Age } \\
\text { Maximal breathing capacity } \\
\text { Maximal expiratory flow rate } \\
\text { Maximal inspiratory flow rate } \\
\text { Airway resistance and \% change after bronchodilator }\end{array}$ & $\begin{array}{c}32 \\
150(8) \\
476(19) \\
390(40) \\
1.37(0.26) \\
-29 \%\end{array}$ & $\begin{array}{c}43 \\
84(9) \\
213(36) \\
226(18) \\
2.94(0.25) \\
-44 \%\end{array}$ & $\begin{array}{l}82 \\
38(5) \\
132(25) \\
135(25) \\
1.30(0.21)\end{array}$ \\
\hline
\end{tabular}

* Mean values, and standard error (in parentheses).

$\dagger$ Eleven patients were studied. Of these, 6 had accidentally inhaled toxic vapors, and 5 had undergone lengthy industrial exposure to particulate matter (carbon, silica, and iron particles). Other findings in these patients were increased residual volume, uneven ventilation, slight hypoxemia, and gas trapping.

conductance was plotted against esophageal pressure. Figure 6 shows the effect of bronchodilator drugs in the normal and in the asthmatic state.

Airway resistance and other tests of pulmonary function in patients with chronic bronchitis. We studied several patients who had been exposed to chemical vapors or particulate matter in the inspired air and who subsequently developed clinical evidence of chronic bronchitis (Table V). These patients had no prior history suggestive of asthma or emphysema. The airway resistance was elevated in most. However, there was an appreciable response to bronchodilator drugs. Values for airflow obtained from tests of forced voluntary ventilation, although depressed, were not so low as is usual in fully developed emphysema. By contrast, normal elderly people had impairment of forced voluntary ventilation but normal airway resistance.

An acute exposure of normal subjects to carbachol aerosol or inert particles dispersed in the inspired air had resulted in an elevation of airway resistance with little or no change in maximal expiratory flow rate (Table VI). At the onset of

TABLE VI

Response of normal subjects to carbachol aerosol or inert particles *

\begin{tabular}{lll}
\hline \hline & \multicolumn{1}{c}{ Before } & \multicolumn{1}{c}{ After } \\
\hline Airway resistance $\dagger$ & $1.37(0.26)$ & $2.63(0.49)$ \\
Maximal expiratory flow rate & $476(19)$ & $464(28)$ \\
\hline
\end{tabular}

* Mean values, and standard error (in parentheses).

$\dagger$ These airway resistance values were reported previously in this journal (6). Values for maximal expiratory flow rate reveal that a moderate degree of bronchoconstriction may be overlooked unless suitable methods are used for its measurement. forced expiration the airways may be widely dilated owing to lung elastic pressure; during forced expiration they tend to collapse from positive intrapleural pressure. We concluded that changes in the state of the airways, while adequately reflected in measurements of airway resistance, were sometimes obscured or erroneously interpreted when forced voluntary ventilation was being used.

\section{DISCUSSION}

The airway conductance, measured in the body plethysmograph by relating alveolar pressure to airflow at the mouth, presumably depends upon the patency, number and length of the conducting airways. It remained relatively constant over several hours in normal subjects. Others have shown that the airway conductance increased at larger lung volumes (1); the present results indicate that it varies directly with lung elastic pressures and that its relationship to lung volume is determined by the pressure-volume behavior of the lung. Thus, at the same lung volume there was a rise in airway conductance when the lung elastic pressure was increased following chest constriction. This was presumably due to an enlargement of the airways as a result of the greater pull on their walls and not to a relaxation of the tone in the walls. There was no evidence that the number of patent airways was increased under these conditions; in fact it was more likely that there were fewer, since there was some evidence of gas trapping (7). This effect of lung elastic pressure on airway conductance had been suggested before (8-11) but had not been established experimentally. 
Atropine subcutaneously, and isoproterenol by aerosol, increased airway conductance in normal subjects in the absence of any alteration in lung elastic pressure. This suggested that these drugs, by their action in reducing active (tonic) effects in the airway wall, had allowed a greater distention of the airway from the passive (mechanical) effects of the existing lung elastic pressure. However, mucosal shrinkage as well as decrease of tone may be concerned in this rise of airway conductance and our studies do not distinguish between them. Breathing oxygen, carbon dioxide or water aerosol produced no significant change in the airway conductance.

When the airway conductance was reduced by disease (asthma, bronchitis, emphysema) there was less than the normal change in airway conductance from alterations of lung elastic pressure. The distensibility of the airways appeared to be decreased. Furthermore, both the lung elastic pressure and the lung volume at which the airway conductance approached zero, obtained by extrapolation, were increased in these patients. This suggested that gas trapping occurred at greater than normal transpulmonary pressures and lung volumes.

Bronchodilator drugs produced striking results in asthma, a greater-than-expected response in bronchitis of toxic etiology, and some response in emphysema. The relationship of airway conductance to both esophageal pressure and lung volume was altered toward normal by these drugs. They appeared to improve airway distensibility and to reduce the lung volume at which the airway conductance approached zero. However, it is often impossible to distinguish between asthma and emphysema by a therapeutic test with these drugs, since both may respond or be refractory to isoproterenol.

We found that forced breathing or exercise in asthmatic patients may decrease the airway conductance while tending to increase the FRC. This has been suspected clinically but experimental confirmation was lacking. The mechanism of this response is unknown, but it is presumably dependent upon changes in the airway wall, the lung elastic pressure at different volumes being unchanged or increased.

Unsuspected degrees of airway obstruction, uneven ventilation, and arterial oxygen desaturation were found in certain cases of bronchitis of toxic etiology. Maximum flow rates were not so reduced as in emphysema. By contrast, in healthy old age there was a reduction in the maximum flow rates which was not associated with any increase in airway resistance. It appeared to be due to a reduction in the power of the respiratory muscles, the maximum pressure generated at the mouth being reduced in most subjects. There was an increase in the lung tissue resistance of some of these older subjects. Our results may be compared with and extend those of other workers $(12,13)$.

We have isolated and described some of the factors that affect the balance which we believe to exist between the tension of the airway wall and the transmural pressure gradient imposed by the elastic pull of the lung. However, assuming some degree of regulation of airway patency, we have shown little about the control system. Among other factors still to be explored are the effects of diminished oxygen and $\mathrm{CO}_{2}$ tension, altered $\mathrm{pH}$, lesions of the nervous system, and psychogenic and endocrine factors. Our methods appear to be satisfactory for this type of observation in man.

\section{SUMMARY}

The effects on airway conductance (the reciprocal of airway resistance) of chest strapping, bronchomotor drugs, exercise, forced breathing, oxygen, carbon dioxide, and old age, were measured in normal subjects and compared with similar observations in patients with asthma, bronchitis and emphysema. Airway conductance was found to be dependent upon lung elastic pressure rather than on lung volume. This relationship was altered by bronchomotor drugs. Breathing oxygen and different concentrations of carbon dioxide did not alter the airway resistance. In several patients with mild asthma, airway resistance increased after forced breathing or exercise. In normal subjects, airway conductance appeared to depend upon a balance of forces between the tension in the airway walls and the opposing transmural pressure gradient due to the elastic traction of the lung. The airway conductance was found to be reduced and the balance of forces was altered in patients who had lower airway obstruction. 


\section{ACKNOWLEDGMENTS}

The authors are grateful to Dr. Julius H. Comroe, Jr., for helpful advice. We acknowledge the collaboration of Comdr. Robert L. Burdick, MC, USN, of the Air Crew Equipment Laboratory, Philadelphia, in the evaluation of the effects of breathing oxygen, and of Drs. W. A. Briscoe and J. Zabara in other parts of this work. We appreciate the cooperation of the ten older normal subjects and the officers of the Stephen Smith Home for the Aged.

\section{REFERENCES}

1. Briscoe, W. A., and DuBois, A. B. The relationship between airway resistance, airway conductance and lung volume in subjects of different age and body size. J. clin. Invest. 1958, 37, 1279.

2. DuBois, A. B., Botelho, S. Y., and Comroe, J. H., Jr. A new method for measuring airway resistance in man using a body plethysmograph: Values in normal subjects and in patients with respiratory disease. J. clin. Invest. 1956, 35, 327.

3. Mead, J., and Whittenberger, J. L. Physical properties of human lungs measured during spontaneous respiration. J. appl. Physiol. 1953, 5, 779.

4. Caro, C. G., Butler, J., and DuBois, A. B. Effects of chest strapping on lung mechanics. Physiologist 1958, 1 (no. 4), 8 .

5. DuBois, A. B., Botelho, S. Y., Bedell, G. N., Marshall, R., and Comroe, J. H., Jr. A rapid plethysmographic method for measuring thoracic gas volume: A comparison with a nitrogen washout method for measuring functional residual capacity in normal subjects. J. clin. Invest. 1956, 35, 322.

6. DuBois, A. B., and Dautrebande, L. Acute effects of breathing inert dust particles and of carbachol aerosol on the mechanical characteristics of the lungs in man. Changes in response after inhaling sympathomimetic aerosols. J. clin. Invest. 1958, 37, 1746.

7. Caro, C. G. Lung compliance, hysteresis and closure of lung units in man. Fed. Proc. 1959, 18, 23.

8. Fry, D. L., Ebert, R. V., Stead, W. W., and Brown, C. C. Mechanics of pulmonary ventilation in normal subjects and in patients with emphysema. Amer. J. Med. 1954, 16, 80.

9. Shepard, R. H., Campbell, E. J. M., Martin, H. B., and Enns, T. Factors affecting the pulmonary dead space as determined by single breath analysis. J. appl. Physiol. 1957, 11, 241.

10. Martin, H. B., and Proctor, D. F. Pressure-volume measurements on dog bronchi. J. appl. Physiol. 1958, 13, 337.

11. Butler, J., and Arnott, W. M. The work of pulmonary ventilation at different respiratory levels. Clin. Sci. 1955, 14, 703.

12. Frank, N. R., Mead, J., Siebens, A. A., and Storey, C. F. Measurements of pulmonary compliance in seventy healthy young adults. J. appl. Physiol. 1956, 9, 38.

13. Pierce, J. A., and Ebert, R. V. The elastic properties of the lungs in the aged. J. Lab. clin. Med. 1958, 51, 63. 